\title{
The Effects of Financial Performance on Stock Returns: Evidence of Machine and Heavy Equipment Companies in Indonesia
}

\author{
A. Razak ${ }^{1}$, Febrian Vingky Nurfitriana ${ }^{2}$, Desty Wana ${ }^{1}, \operatorname{Ramli}^{1}$, Ismail Umar $^{1} \&$ Endri Endri ${ }^{2}$ \\ ${ }^{1}$ Politeknik Negeri Pontianak, Pontianak, Kalimantan Barat, Indonesia \\ ${ }^{2}$ Universitas Mercu Buana, Jakarta, Indonesia \\ Correspondence: Endri Endri, Lecturer, Universitas Mercu Buana, Jakarta, Indonesia. E-mail: \\ endri@mercubuana.ac.id
}

Received: June 29, 2020

Accepted: September 17, 2020

Online Published: October 8, 2020

doi:10.5430/rwe.v11n6p131

URL: https://doi.org/10.5430/rwe.v11n6p131

\begin{abstract}
This study was made to determine the effect of Current Ratio (CR), Total Assets Turnover (TAT), Return on Assers (ROA), Debt to Equity Ratio (DER) on stock returns in the machinery and heavy equipment sub-sector companies listed on the Stock Exchange Indonesia (IDX) in the period 2014 - 2018. Stock returns are calculated based on changes in closing stock prices and estimated influence of financial performance factors using the panel data regression method. Based on empirical findings show that financial performance that has been proxy using; CR, TAT, ROA, and DER do not affect stock returns. The results of the study have implications that the company's financial performance is not an important consideration for investors in the decision to buy shares in the Machinery and Heavy Equipment sub-sector company. In many studies, stock prices are much influenced by macroeconomic variables, such as; exchange rates, inflation, interest rates, and oil prices
\end{abstract}

Keywords: stock return, current ratio, total asset turnover, return on asset, debt to equity ratio

JEL Clasifications: G1, G3

\section{Introduction}

Heavy equipment and machine sub-sector companies are included in various industry sector groups which are listed on the Indonesia stock exchange. The multifarious industry sector is the largest contributor to strengthening the Composite Stock Price Index on the Indonesia Stock Exchange (IDX). Based on idx.co.id data, as of May 2020 the multifarious industry sector experienced the biggest increase of 3.9\%, followed by infrastructure which increased $2.44 \%$ and mining which increased $2.42 \%$. Positive developments in the various industry sectors, especially the heavy equipment and machinery sub-sector, have had an impact on rising share prices.

The increase in stock returns of heavy equipment and machine companies is a reflection of a good company's financial performance. Financial performance is measured using a ratio; liquidity, activity, solvency and profitability, based on financial statements from the heavy equipment and machinery sub-sector during the period 2014 - 2018 showed an improved performance. Liquidity ratios show high yields, meaning companies in the heavy equipment and machinery sub-sector are able to meet or pay off their short-term obligations fairly well. The activity ratio shows that the machinery and heavy equipment sub-sector company is able to use its assets quite efficiently. The solvency ratio shows that the machine and heavy equipment company has a high enough number so that this causes the company to have a greater obligation than the capital it has. The profit gained by shareholders from the relatively small income is shown through the calculation of ROA and ROE which have relatively small values.

Investors' decision to benefit from shares held over a certain period of time takes into account the company's financial performance more (Fathony et al., 2020). Stock returns from the perspective of large investors are sourced from rising stock prices from one period to the next is known as capital gains, while minority shareholders target the company's ability to distribute dividends, calculated through dividend yields. The shareholders try to reinvest the profits generated with the consequence of not distributing dividends with the aim that the company's future prospects are better and will have an impact on future stock price increases. Share prices represent investors' expectations regarding future cash flows, the company's ability to create value for shareholders (Endri et al., 2020). This study aims to estimate the effect of traditional financial factors on stock returns. Financial factors are considered through 
ratios provided by the annual financial statements, which consist of; liquidity, activity, solvency, and profitability on stock returns using the panel data regression method in the Machinery and Heavy Equipment sub-sector companies included in the manufacturing industry listed on the Indonesia Stock Exchange (IDX)

\section{Literature Review}

Empirical research related to the effect of financial performance on stock returns has been done a lot but it still gives contradictory results. Research by Setiyawan \& Pardiman (2014) on consumer goods manufacturing companies listed on the IDX for the 2009-2012 period showed that CR, ROE and Time Interest Earned had a positive effect on stock prices, while Inventory Turnover had no effect on stock prices. CR, Inventory Turnover, Time Interest Earned and ROE simultaneously influence stock prices. Research from Wardoyo \& Veronica (2013) shows that the resulting ROA and ROE have a significant effect on company value, while the size of the board of commissioners, the independence of the board of commissioners, the number of audit committee members and CSR have no significant effect on the value of the company. Study of Dita \& Murtaqi (2014) showed that NPM, PBV, and DER had a significant effect on stock returns, two of which, namely NPM and DER had a significant positive effect on stock returns, while prices for book value had a significant negative relationship to stock returns.

In the research of Petcharabul \& Romprasert (2014) by using Ordinary Least-Squares Regression (OLS estimate) to test the relationship between financial ratios and stock returns and found that only ROE and PE have a significant relationship with stock returns. Karaca \& Savsar (2012) by using panel data analysis, empirical findings indicate that financial ratios affect firm value. There is a significant and positive relationship between accounts receivable turnover and firm value; There is a significant and negative relationship between inventory turnover and returns on equity. No significant relationships were detected between other ratios. Then there is also research from Amalya (2018) obtaining results using the (F test) shows that company performance as measured by ROA, ROE, NPM and DER has a significant effect on stock prices. Partially with the (t test) it was concluded that partially the ROA, ROE and DER variables did not significantly influence the stock price, while the NPM variable significantly affected the stock price. Benyamin \& Endri (2019) tested the effect of ROE, EPS, DER, and market share (MS) on stock returns on buildings construction sector companies listed on the Indonesia Stock Exchange for the period 2012-2016 use a random effects regression model. Empirical findings indicate that ROE and MS have positive effect; EPS has a negative effect, while DER has no negative effect on stocks return.

This is also the same as study of Murhadi (2013) which says that the results of idiosyncratic risk have a significant negative effect on stock returns, stock liquidity has a significant positive effect, and company size has a significant negative effect. The results of this study are consistent with the results of the research Wijaya (2008) which says that the independent variables (ROE, PER, BVPS, and PTBV) do not significantly influence the dependent variable In contrast to the research of Ulupui (2007) which says that the variables used in the test CR and ROA are positive and have a significant effect on stock returns, and in research of Allozi \& Obeidat (2016), the results showed that GPM, ROA, ROE, and EPS have a significant relationship with stock returns. And the others, NPM and leverage (DR, DER), and (CR)) do not have a significant relationship with stock returns. Endri et al., (2019) conducted a study of the effect of financial ratio factors on stock returns with a sample of food and beverage sector companies listed on the Indonesia Stock Exchange in 2013-2017 using the panel data regression method. Partial testing shows that leverage affects the movement of stock returns negatively, whereas ROA and EPS have positive effects. Conversely, the CR and PER variables do not affect the movement of stock returns. Test results cumulatively shows that all independent variables simultaneously influence stock returns.

\section{Research Methods}

This study uses secondary data based on company financial reports published by the Indonesia Stock Exchange through www.idx.org. The sample used in this study was three companies in the machinery and heavy equipment sub-sector listed on the Indonesia Stock Exchange during the period 2014 - 2018 that published complete and consistent financial statements. Research focus on estimating the effect of financial performance on stock returns (dependent variable), where financial performance variables (independent variables) consist of; Current Ratio (CR), Total Asset Turnover (TAT), Return on Assets ROE) and Debt to Equity Ratio (DER). The method used to estimate the effect of financial performance variables on stock returns is a panel data regression analysis. Panel data regression method consists of three models, namely; Common Effect Model (CEM), Fixed Effect Model (FEM), and Random Effect Model (REM) (Sugianto et al., 2020). To determine the selected model which is then used to estimate and analyze the effect of financial performance variables on stock returns based on the model selection test, namely; Chow Test, Hausman Test, and Lagrange-Multiplier Test 


\subsection{Independent Variable}

Is a variable that is the cause of the emergence of the dependent variable. Following are the independent variables used:

\section{(a) Current Ratio}

Current Ratio is intended as a reference to measure a company's ability to pay off liabilities in the short term (Endri et al., 2020). The higher the value of CR, the greater the industry can pay its short-term liabilities, this way the company can be said to be a good company.

$$
C R=\frac{\text { Current Asset }}{\text { Current Debt }} \times 100 \%
$$

(b) Total Aset Turnover

For the measurement of a turnover of all assets collected and calculate the sum of the sales results obtained from the assets of each rupiah (Wijaya, 2017).

$$
T A T=\frac{\text { Sales }}{\text { Total Assets }}
$$

(c) Return on Aset

This ratio aims to see the financial potential of a company in generating profit, income, profits, assets, and share capital. (Sari \& Endri, 2019).

$$
R O A=\frac{\text { Net Income }}{\text { Total Assets }}
$$

\section{(d) Debt to Equity Ratio}

Debt to Equity Ratio is a comparison between the amount of debt and the amount of equity, the higher the DER value, the greater the existing debt in the company (Mahardika \& Marbun, 2016).

\subsection{Dependent Variable}

The dependent variable is the stock price of each industry. Stock prices are investments that will change in value over time (from time to time). For the value of the stock price used as research material is close priced at the end of each year from 2014 - 2018. Stock return is a main goal of a person or company in investing. In this method the measurement of stock returns will be used as the dependent variable. Which formula is as follows:

$$
R_{i . t}=\frac{P_{i . t}-P_{i . t-1}}{P_{i . t-1}}
$$

For Information:

$$
\begin{array}{ll}
R_{i . t} & =\text { Current Return } \\
P_{i . t} & =\text { Current stock price } \\
P_{i . t-1} & =\text { Share price last period }
\end{array}
$$

Capital gains occur if the current stock price $P_{i . t}$ greater than the share price last period $P_{i . t-1}$ capital-gain. Conversely, if you experience a drastic reduction or loss is usually called capital-loss.

\subsection{Data Analysis Method}

In this study the method used is panel data regression analysis, following the equation :

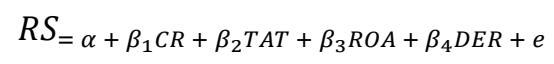

Information:

$$
\begin{array}{ll}
\alpha & =\text { A constant } \\
\beta_{1} \beta_{2} \beta_{3} & =\text { The coefficient of the independent variable } \\
\mathrm{RS} & =\text { Stock return } \\
\mathrm{CR} & =\text { Current Ratio } \\
\mathrm{TAT}=\text { Total Assets Turnover }
\end{array}
$$


ROA = Return on Assets

$\mathrm{DER}=$ Debt to Equity Ratio

e $\quad=$ Term error

\section{Result and Discussions}

\subsection{Results}

Panel data regression analysis is the analysis used as a method for analyzing data by using the chow, hausman, and lagrange testing methods. By using three effect models it aims to determine the best model that will be used in this study, by using the eviews 10 application the writer can process the data and can do several tests. Here are the results of the data and its hypotheses:

Table 1. Result Chow Test

\begin{tabular}{llrc}
\hline Effects Test & Statistic & d.f. & Prob. \\
\hline Cross-section F & 4.391684 & $(2,8)$ & 0.0516 \\
Cross-section Chi-square & 11.114202 & 2 & 0.0039 \\
\hline
\end{tabular}

Source: Data Processed (2020)

$H_{0}=$ CEM Model (Common Effect Model) selected (if Prob. > 0,05)

$H_{1}=$ FEM Model (Fixed Effect Model) selected (if Prob.<0,05)

Based on the chow test results table, the prob value for both models has a prob value>0.05. The common effect model is a good model to choose from. But this model is not necessarily good, because it must compare all models to be able to see the final results of a good model used. That way there is a need for a multiplier test diagram.

Table 2. Result Hausman Test

\begin{tabular}{lrrr}
\hline Test Summary & Chi-Sq. Statistic & Chi-Sq. d.f. & Prob. \\
\hline Cross-section random & 0.000000 & 4 & 1.0000 \\
\hline
\end{tabular}

Source: Data Processed (2020)

$H_{0}=$ REM Model (Random Effect Model) selected (if Prob. > 0,05)

$H_{1}=$ FEM Model (Fixed Effect Model) selected (if Prob. <0,05)

Based on the results of the hausman test table seen, the value of 1.0000>0.05. A good random effect model is chosen. But this model is not necessarily good, because the random effect model must compare with the common effect model. That way it is necessary to have a lagrange multiplier test.

Table 3. Result Lagrange Multiplier Test

\begin{tabular}{lccc}
\hline Null (no rand. effect) & Cross-section & Period & Both \\
\hline Alternative & One-sided & One-sided & \\
Breusch-Pagan & 0.161117 & 0.897924 & 1.059040 \\
& $(0.6881)$ & $(0.3433)$ & $(0.3034)$ \\
Honda & -0.401393 & -0.947588 & -0.953874 \\
& $(0.6559)$ & $(0.8283)$ & $(0.8299)$ \\
King-Wu & -0.401393 & -0.947588 & -0.874827 \\
& $(0.6559)$ & $(0.8283)$ & $(0.8092)$ \\
GHM & -- & -- & 0.000000 \\
& -- & -- & $(0.7500)$ \\
\hline
\end{tabular}

Source: Data Processed (2020) 
$H_{0}=$ Model CEM (Common Effect Model) selected (if Prob. > 0,05)

$H_{1}=$ Model REM (Random Effect Model) selected (if Prob. <0,05)

Based on the table of the Lagrange multiplier test results it can be seen that the value of the bre-breach prob is 0.6881 , which means that $H_{1}$ is rejected and $H_{0}$ is accepted. Then a good common model effect is chosen. So it can be concluded, a good model is the common effect model. Following are the results of data from the common effect model:

Table 4. Result Common Effect Model

\begin{tabular}{crccc}
\hline Variable & Coefficient & Std. Error & t-Statistic & Prob. \\
\hline C & 0.375349 & 0.910457 & 0.412265 & 0.6888 \\
CR & 0.136370 & 0.471265 & 0.289370 & 0.7782 \\
TAT & 0.274443 & 1.616838 & 0.169741 & 0.8686 \\
ROA & -5.459940 & 5.749008 & -0.949719 & 0.3646 \\
DER & -0.152099 & 0.128934 & -1.179669 & 0.2654 \\
\hline
\end{tabular}

Source: Data Processed (2020)

Table 5. R-Squared $\left(\mathrm{R}^{2}\right)$ Test \& F-Test

\begin{tabular}{lrlc}
\hline R-squared & 0.139409 & Mean dependent var & 0.226939 \\
Adjusted R-squared & -0.204828 & S.D. dependent var & 0.513178 \\
S.E. of regression & 0.563288 & Akaike info criterion & 1.951151 \\
Sum squared resid & 3.172937 & Schwarz criterion & 2.187168 \\
Log likelihood & -9.633634 & Hannan-Quinn criter. & 1.948637 \\
F-statistic & 0.404979 & Durbin-Watson stat & 2.100805 \\
Prob(F-statistic) & 0.801083 & & \\
\hline
\end{tabular}

Source: Data Processed (2020)

Based on the tests that have been done, in this study the researchers used a hypothesis that applies to the $\mathrm{F} \& \mathrm{t}$ test, the hypothesis is as follows:

$H_{0}=$ Not significant; $H_{1}=$ Significant

In the $t$ test or partial test it can be seen that the results of the $t$ test show the independent variable value $>0.05$, meaning that the value of Prob. $>\alpha$ then $H_{0}$ is accepted and $H_{1}$ is rejected. Or it can be said that the independent variable has no significant effect on the dependent variable. In this $\mathrm{F}$ test the researcher uses Prob (F-Statistic) or p-value, wherein the Prob (F-Statistic) must be compared with a significant level or $\alpha(\alpha=0.05)$. Then the F test results or the simultaneous test has a result of 0.80 this means that Prob (F-Statistics) $>\alpha$ then $H_{0}$ is accepted and $H_{0}$ is rejected. Or it can be said that the independent variable has no significant effect on the dependent variable. And for the R-Squared $\left(R^{2}\right)$ test the results obtained from R-Squared $\left(\left(R^{2}\right)\right.$ are 0.139409 , meaning that the dependent variable can affect the dependent variable by $13.94 \%$ (0.139409). While the remaining $86.06 \%(0.860691)$ is influenced by other variables outside the study. So the results of the $\mathrm{R}^{2}$ test are the independent variables do not significantly influence the dependent variable. Because the hypothesis in this R2 test is if the value of R-Squared (R2) is greater than 0.5 then the ability of the independent variable is strong in explaining the dependent variable, but conversely if the value of $\mathrm{R}^{2}$ is less than 0.5 then the ability of the independent variable is not strong in explaining dependent variable

\subsection{Discussion}

Based on panel data regression analysis that has been done, this aims to determine whether the independent variable influences the dependent variable. This research was conducted by calculation using Eview10, and the results are:

\section{Effect of CR on Stock Returns}

Based on the results of panel data regression, it can be seen that CR has no significant effect on stock returns. The 
results of this study are consistent with the results of research conducted by Öztürk \& Karabulut (2018); Lewellen (2004); Srinivasan (2012); Petcharabul \& Rompasert (2014); Dita \& Murtaqi (2014); Endri et al., (2019). In contrast with the results of research by Gharaibeh (2014); Uluyol \& Turk (2013); Kalayci \& Karatas (2005); Ulupui (2007); Setiyawan \& Pardiman (2014); which proves that CR has a significant effect on stock returns

\section{The Influence of TATO on Stock Returns}

Based on the results of panel data regression that has been done, it can be seen that the resulting TAT has a positive value that has no significant effect on stock returns. The results of this study are consistent with the research of Firmansyah (2017); Asmi (2014). While this research is inversely proportional to the research of Patin et al., (2020); Karaca \& Savsar (2012); Vedd \& Yassinski (2015); Azadi (2013); Jose et al., (2011) who say that the total assets are turnover significant effect on stock returns.

\section{Effect of ROA on Stock Returns}

Based on the results of panel data regression, it can be seen that the ROA generated has a positive value and has no significant effect on stock returns. These results are in line with research conducted by Firmansyah (2017); Indarti \& Dini (2012). While this research is inversely related to research conducted by Allozi \& Obeidat (2016); Petcharabul \& Rompasert (2014); Dadrasmoghaddam \& Akbari (2015); Ulupui (2007); Ilmiyono (2019); Sari \& Endri (2019); Shahnia et al., (2020) who say that ROA values are positive and has a significant effect on stock returns.

\section{Effect of DER on Stock Returns}

Based on the results of panel data regression that has been done, it can be seen that the DER obtained has a negative value and has no significant effect on stock returns. The results of this study are consistent with research conducted by Allozi \& Obeidat (2016); Sivilianto \& Endri (2019). This research is inversely proportional to research conducted by Dadrasmoghaddam \& Akbari (2015); Dita \& Murtaqi (2014); Endri (2018); Harahap et al., (2020) who say that DER values are positive and influential significant to stock returns.

\section{Conclusions}

In the explanation above it can be concluded that the results of panel data regression analysis and passing several tests, such as the chow, hausman, and lagrange multiplier tests can produce a good effect model used is the CEM (common effect model). With the CR results no significant effect on stock returns, TAT has no significant effect on stock returns, ROA has no significant effect on stock returns, and DER has no effect on stock returns. Advice can be given is for the management of each company in order to improve financial performance in the machinery and heavy equipment sub-sector. Because by looking at the current conditions, it can be seen that the financial performance of this sub-sector has not been considered good. This can be seen from the independent variables that do not produce significant results on stock returns so that the lack of competition in the future. With this research, it is expected that companies in the machinery and heavy equipment sub sector can increase the volume of financial performance with other supporting aspects or variables.

\section{References}

Allozi, N. M., \& Obeidat, G. S. (2016). The Relationship between the Stock Return and Financial Indicators (Profitability, Leverage): An Empirical Study on Manufacturing Companies Listed in Amman Stock Exchange. Journal of Social Sciences, 5(3), 408-424.

Amalya, N. (2018). Pengaruh Return on Aset, Return on Equity, Net Profit Margin dan Debt to Equity Rasio Terhadap Harga Saham. Jurnal SEKURITAS, 1(3), 157-181. https://doi.org/10.32493/skt.v1i3.1096

Azadi, M. (2013). The relationship between changes in asset structure and operating earnings in the Tehran Stock Exchange (TSE). Trends in Advanced Science \& Engineering (TASE), 7(1), 30-34.

Benyamin, I. A., \& Endri, E. (2019). Determinants of Stock Returns of Building Construction Companies Listed on the Indonesia Stock Exchange Period 2012-2016. Scholars Journal of Economics, Business and Management, 6(1), 39-47. https://doi.org/10.21276/sjebm.2019.6.1.6

Dadrasmoghaddam, A., \& Akbari, S. M. (2015). Relationship between Financial Ratios in the Stock Prices of Agriculture-Related Companies Accepted on the Stock Exchange for Iran. Research Journal of Fisheries and Hydrobiology, 10(9), 586-591

Dita, A. H., \& Murtaqi, I. (2014). The Effect of Next Profit Margin, Price to Book Value and Debt to Equity Ratio to stock Return in the Indonesian Consumer Goods Sector. Journal of Business and Management, 3(3), 305-315.

Endri, E., Dermawan, D., Abidin, Z., \& Riyanto, S. (2019). Effect of Financial Performance on Stock Return: 
Evidence from the Food and Beverages Sector. International Journal of Innovation, Creativity and Change, 9(10), 335-350.

Endri, E., Sumarno, A., \& Saragi, H. (2020). Analysis of Financial Performance: Evidence from Food and Beverage Companies in Indonesia. International Journal of Advanced Science and Technology, 29(5), 4199-4208.

Endri. (2018). Determinan Internal Harga Saham Perusahaan BUMN Non Bank yang Terdaftar di Bursa Efek Indonesia. ULTIMA Accounting, 10(2), 124-137.

Fathony, M., Khaq, A., \& Endri, E. (2020). The Effect of Corporate Social Responsibility and Financial Performance on Stock Returns. International Journal of Innovation, Creativity and Change, 13(1), 240-252.

Firmansyah, M. (2017). Pengaruh Pertumbuhan Perusahaan, Total Aset Turnover, Return On Investment, Earning Per Share Terhadap Harga Saham (Studi Perusahaan Manufaktur di BEI). Asian Journal of Innovation and Entrepreneurship (AJIE), 2(2), 110-121. https://doi.org/10.20885/ajie.vol2.iss2.art3

Gharaibeh, A. (2014). Capital Structure, Liquidity and Stock Returns. European Scientific Journal, 10(2), 171-179.

Harahap, I. M., Septiania, I., \& Endri, E. (2020). Effect of financial performance on firms' value of cable companies in Indonesia. Accounting, 6(6), 1103-1110. https://doi.org/10.5267/j.ac.2020.7.008

Ilmiyono, A. F. (2019). The Effect of ROE, ROA and EPS toward Stock Prices in Companie sub Sektor Construction and Buildings Listed in Exchange Indonesia Effect (IDX). International Journal of Latest Engineering and Management Research (IJLEMR), 4(8), 24-35.

Indarti, I., \& Dini, A. (2012). Pengaruh Net Profit Margin (NPM), Return On Assets (ROA) dan Return On Equity (ROE) Terhadap Harga Saham yang Terdaftar dalam Indeks Emiten LQ45 Tahun 2008 - 2010. Jurnal Kajian Akuntansi dan Bisnis, 1(1), 1-18. https://doi.org/10.1103/PhysRevB.95.064517

Jose, M. L., Lancaster, C., \& Stevens, J. L. (2011). Stability of excellence: Revealed patterns in Tobin's Q-ratios. Journal of Applied Business Research, 12(2), 83-91.

Kalayci, S., \& Karatas, A. (2005). Relationship between Common Stock Returns and Financial Ratios: A Research of Fundamental Analysis in ISE. Muhasebe ve Finansman Dergisi, 27, 146-157.

Karaca, S. S., \& Savsar, A. (2012). The Effect of Financial Ratios on the Firm Value: Evidence from Turkey. Journal of Applied Economic Sciences, 7(1), 56-63.

Lewellen, J. (2004). Predicting Returns with Financial Ratios. Journal of Financial Economics, 74, 209-235. https://doi.org/10.1016/j.jfineco.2002.11.002

Mahardika, P. A., \& Marbun, D. P. (2016). Pengaruh Current Rasio Dan Debt to Equity Rasio Terhadap Return On Asstes. Widyakala Journal, 3, 23-28. https://doi.org/10.36262/widyakala.v3i0.21

Murhadi, W. R. (2013). Pengaruh Idiosyncratic Risk dan Likuiditas Saham Terhadap Return Saham. Jurnal Manajemen dan Kewirausahaan, 15(1), 33-39. https://doi.org/10.9744/jmk.15.1.33-40

Öztürk, H., \& Karabulut, T. A. (2018). The Relationship between Earnings-to-Price, Current Ratio, Profit Margin and Return: An Empirical Analysis on Istanbul Stock Exchange. Accounting and Finance Research, 7(1), 109-115. https://doi.org/10.5430/afr.v7n1p109

Patin, J. C., Rahman, M., \& Mustafa, M. (2020). Impact of Total Asset Turnover Ratios on Equity Returns: Dynamic Panel Data Analyses. Journal of Accounting, Business and Management (JABM), 27(1), 19-29.

Petcharabul, P., \& Romprasert, S. (2014). Technology Industry on Financial Ratios and Stock Returns. Journal of Business and Economics, 5(5), 739-746.

Sari, F. N., \& Endri, E. (2019). Determinants of Return on Assets (ROA) On Conventional Banks Listed On Indonesian Stock Exchange (IDX) Period 2013 - 2017, IOSR Journal of Business and Management (IOSR-JBM), 21(4. Ser. II), 52-62. https://doi.org/10.9790/487X-2104025262

Setiyawan, I., \& Pardiman. (2017). Pengaruh Current Rasio, Inventory Turnover, Time Interest Earned dan Return on Equity Terhadap Harga Saham Pada Perusahaan Manufaktur Sektor Barang Konsumsi Yang Tersaftar di BEI Periode 2009 - 2012. Nominal, Barometer Riset Akuntansi dan Manajemen, 3(2), 117-133. https://doi.org/10.21831/nominal.v3i1.2152

Shahnia, C., Purnamasari, E. P., Hakim, L., \& Endri, E. (2020). Determinant of profitability: Evidence from trading, service and investment companies in Indonesia. Accounting, 6(5), 787-794. 
https://doi.org/10.5267/j.ac.2020.6.004

Sivilianto, H., \& Endri, E. (2019). Determinants of External and Internal Stock Price of Coal Mining Subsector Companies Period 2005-2017. Scholars Bulletin, 5(4), 162-168. https://doi.org/10.21276/sb.2019.5.4.5

Srinivasan, P. (2012). Determinants of Equity Share Prices in India: A Panel Data Approach. The Romanian Economic Journal, 46, 205-228.

Sugianto, S., Oemar, F., Hakim, L., \& Endri, E. (2020). Determinants of Firm Value in the Banking Sector: Random Effects Model. International Journal of Innovation, Creativity and Change, 12(8), 208-218.

Ulupui, I. (2007). Analisis Pengaruh Rasio Likuiditas, Leverage, Aktivitas, dan Profitabilitas Terhadap Return Saham (Studi Pada Perusahaan Makanan dan Minuman Dengan Kategori Industri Barang Konsumsi di BEJ). Jurnal Ilmiah Akuntansi dan Bisnis, 2(1), 1-20.

Uluyol, O., \& Turk, V. E. (2013), Finansal Rasyolarun Firma Değerine Etkisi: Borsa İstanbul (BİST)'da Bir Uygulama. Afyon Kocatepe Universitesi IIIBF Dergisi, 4(2), 365-384.

Vedd, R., \& Yassinski, N. (2015). The Effect of Financial Ratios, Firm Size \& Operating Cash Flows on Stock Price: Evidence from the Latin America Industrial Sector. Journal of Business and Accounting, 8(1), 15-26.

Wardoyo, \& Veronica, T. M. (2013). Pengaruh Good Corporate Governance, Corporate Social Responsibility \& Kinerja Keuangan Terhadap Nilai Perusahaan. Jurnal Dinamika Manajemen, 4(2), 132-149.

Wijaya, D. (2008). Pengaruh Rasio Modal Saham Terhadap Return Saham Perusahaan - Perusahaan Telekomunikasi Go Public di Indonesia Periode 2007. Jurnal Manajemen dan Kewirausahaan, 10(2), 136-152. https://doi.org/10.9744/jmk.10.2.pp.136-152

Wijaya, R. (2017). Kinerja Keuangan dan Ukuran Perusahaan Terhadap Harga Saham dengan Kebijakan Dividen Sebagai Variabel Intervening. Jurnal Keuangan dan Perbankan, 21(3), 459-472. https://doi.org/10.26905/jkdp.v21i3.1432

\section{Copyrights}

Copyright for this article is retained by the author(s), with first publication rights granted to the journal.

This is an open-access article distributed under the terms and conditions of the Creative Commons Attribution license (http://creativecommons.org/licenses/by/4.0/). 